\title{
Stage II Vulvar Cancer AJCC v8
}

National Cancer Institute

\section{Source}

National Cancer Institute. Stage II Vulvar Cancer A/CC v8. NCI Thesaurus. Code C139622.

Stage II includes: T2, N0, M0. T2: Tumor of any size with extension to adjacent perineal structures (lower/distal third of the urethra, lower/distal third of the vagina, anal involvement). NO: No regional lymph node metastasis. MO: No distant metastasis. (AJCC 8th Ed.) 